\title{
EKSPLORASI RUANG EDUKASI KREATIF DALAM WUJUD THIRD PLACE DENGAN METODE KONTEKSTUAL DI KAWASAN HUNIAN PADAT MANGGARAI
}

\author{
Cakra Wirabuana Shelo ${ }^{1)}$, Franky Liauw ${ }^{2)}$ \\ 1)Program Studi S1 Arsitektur, Fakultas Teknik, Universitas Tarumanagara, cakra.shelo@gmail.com \\ 2) Program Studi S1 Arsitektur, Fakultas Teknik, Universitas Tarumanagara, frankyl@ft.untar.ac.id
}

Masuk: 13-07-2020, revisi: 28-07-2020, diterima untuk diterbitkan: 23-09-2020

\begin{abstract}
Abstrak
Pertumbuhan penduduk dan urbanisasi ke pusat kota yang berlebih menyebabkan terjadinya area hunian padat di Kota Jakarta. Dalam pembahasan ini, wilayah yang menjadi perhatian adalah kawasan Kelurahan Manggarai, Jakarta Selatan, terlihat dari banyaknya hunian padat kumuh yang berdiri di sepanjang pinggiran sungai dan sekitar stasiun. Permasalahan keterbatasan lahan pada permukiman menyebabkan teras hunian serta jalan lalu lintas setempat dijadikan tempat berinteraksi antar warganya yang dapat menimbulkan gangguan terhadap area privasi hunian maupun lalu lintas pergerakan warga. Fasilitas penampungan sampah pada kawasan padat juga belum terkelola dengan baik ditinjau dari banyaknya titik penumpukan sampah pada kawasan hunian padat. Lingkup pembahasannya adalah mengenai bangunan publik rekreatif yang dapat menampung interaksi masyarakat hunian padat. Tujuan dan manfaat dari proyek ini, adalah menciptakan wujud ruang antara untuk berinteraksi dan melepas penat antar masyarakat dengan merespon isu manajemen sampah pada kawasan dalam wujud Open Architecture dan Third Place. Metode pengumpulan data diperoleh dari observasi lapangan, serta studi literatur mengenai arsitektur kontekstual sebagai respon perancangan desain pada kawasan hunian padat. Hasil dari penelitian ini sendiri menghasilkan suatu bangunan arsitektur dengan program fungsi lokakarya kreatif dari daur ulang sampah yang dapat menampung interaksi warga secara rekreatif sekaligus edukasi manajemen sampah bagi masyarakat.
\end{abstract}

Kata kunci: edukasi; hunian padat; kontekstual; kreatif; rekreasi

\begin{abstract}
Excessive population growth and urbanization to the city are causing a dense residential area in the city of Jakarta. In this discussion, the area that is the center of attention is Manggarai, South Jakarta, seen from the number of dense residential that stands along the banks of the river and around the station. The problem of limited area in the residential causes terraces and the local road to be used as a place of interaction between citizens, which can cause disturbance to the area of residential privacy and resident movement. Garbage collection facilities in the area are also not well managed in terms of the number of garbage piles in residential areas. The study of the discussion is a recreational public building that can accommodate the interaction of dense residential communities. The purpose and benefits of this project are to create a form of space to interact and release stress between communities by responding to the issue of waste management in the form of Open Architecture and Third Place. Data methods were obtained from field observations, as well as literature studies on contextual architecture as a response to design in dense residential areas. The results of this study produced an architectural building with a program of a creative workshop from waste recycling that could accommodate community interactions in a creative way as well as waste management education for the community.
\end{abstract}

Keywords: contextual; creative; dense residential; education; recreation 


\section{PENDAHULUAN}

\section{Latar Belakang}

Kota merupakan salah satu tempat tinggal dimana kehidupan manusia berlangsung secara kompleks, perkembangan kota amat dipengaruhi oleh aktivitas pengguna yang menyesuaikan perkembangan zaman dan tuntutan hidup. Kota juga mempengaruhi kehidupan segala bidang yang berdampak pada timbulnya masalah-masalah yang kompleks salah satunya adalah kepadatan penduduk. Dari 17.000 pulau di Indonesia, Pulau Jawa merupakan pulau terpadat di Indonesia karena pada tahun 2019 hasil riset dari BPS (Badan Pusat Statistik) mengatakan bahwa 57\% dari total seluruh penduduk di Indonesia berada di Pulau Jawa. Artinya kurang lebih sebanyak 149 juta jiwa penduduk Indonesia bermukim di Pulau Jawa dimana Kota Jakarta yang berperan sebagai Ibu Kota merupakan kota terpadat di Pulau Jawa itu sendiri (16.269 jiwa/km2). Kota Jakarta sebagai pusat pemerintahan, pusat kegiatan ekonomi, serta pusat perdagangan dan jasa menjadi tujuan bagi masyarakat sebagai wadah untuk memenuhi kebutuhan mereka.

Menurut Sujarto (1995) dalam perencanaan tata ruang unsur pembentuk kota, terdapat lima hal pokok yang diangkat menjadi dasar-dasar di dalam perencanaan. Kelima hal tersebut adalah wisma (tempat tinggal), karya (tempat bekerja), marga (jaringan pergerakan), suka (tempat rekreasi/hiburan), dan penyempurna (sarana/fasilitas umum dan sosial). Karena Jakarta merupakan wadah dalam memenuhi kebutuhan dan tempat mencari nafkah bagi masyarakat luas maka banyak terjadinya urbanisasi ke pusat kota dan menimbulkan kebutuhan akan hunian (wisma) di Kota Jakarta. Wilayah hunian yang terbatas dengan pertumbuhan penduduk dan urbanisasi ke pusat kota inilah yang menyebabkan tumbuhnya kawasan-kawasan padat penduduk di daerah Jakarta, yang pada akhirnya menjadi kawasan permukiman yang kumuh. Kawasan padat penduduk merupakan sebuah area atau daerah yang dijadikan tempat tinggal sekelompok orang dengan perbandingan jumlah penduduk yang sangat besar dibandingkan dengan luas daerah yang begitu sempit. Menurut Holahan (1982) kepadatan tinggi merupakan stresor lingkungan yang dapat menimbulkan kesesakan bagi individu yang berada didalamnya. Stresor lingkungan menurut Brigham (1991) merupakan salah satu aspek lingkungan yang dapat menyebabkan stress, penyakit atau akibat-akibat negatif pada perilaku masyarakat.

Menurut Heimstra dan McFarling (1978) kepadatan memberikan akibat bagi manusia baik secara fisik sosial maupun psikis. Dari observasi langsung pada kawasan hunian padat di Kelurahan Manggarai, Jakarta Selatan, terbatasnya area kawasan dan kebutuhan akan tempat tinggal menyebabkan masyarakat lebih mengutamakan area hunian (wisma) dan banyak fungsi ruang lain yang dikesampingkan seperti jaringan pergerakan (marga), area rekreasi (suka) dan area sosial yang bersifat hijau (RTH). Merespon kebutuhan sosial untuk melepas kepenatan, masyarakat menjadikan teras hunian serta jalan lalu lintas pejalan kaki setempat sebagai wadah berinteraksi antar warganya. Area ini difungsikan ke banyak kegiatan seperti tempat berjualan (karya), bermain dan bersantai (suka), menjemur pakaian, dan tempat parkir. Ruang sosial yang ada tidak memadai karena tidak sesuai dengan tata ruang semestinya dan dapat menyebabkan gangguan terhadap fungsi lainnya seperti terganggunya area privasi hunian maupun lalu lintas pergerakan warga pada kawasan. Alasan lain dari tidak memadainya ruang sosial warga adalah fasilitas penampungan sampah pada kawasan padat yang belum terkelola dengan baik ditinjau dari banyaknya titik penumpukan sampah pada kawasan. Dengan manajemen sampah yang buruk, timbunan sampah dari berbagai macam kategori dapat tercampur dan mengganggu kesehatan warga serta mencemari lingkungan hidup.

Dengan adanya kebutuhan sosial masyarakat untuk berinteraksi diharapkan adanya peran ruang antara yang bukan sebagai tempat untuk tinggal (home) dan untuk bekerja (work) 
melainkan untuk rekreasi dan melepas penat antar masyarakat dapat diwujudkan dalam Open Architecture dan Third Place pada kawasan. Isu dari manajemen sampah pada kawasan dijadikan sebagai potensi dalam menetapkan program penyelesaian yang bertujuan sebagai dasar interaksi kegiatan rekreasi warga dan sarana edukasi mengenai manajemen sampah yang diharapkan dapat mereduksi permasalahan pada kawasan.

\section{Rumusan Permasalahan}

Berdasarkan latar belakang yang ada diketahui terdapat masalah yang terjadi, yaitu:

a. Bagaimana Third Place dapat menjadi solusi dan tanggapan dari kebutuhan warga akan ruang sosial di tengah kawasan hunian padat?

b. Bagaimana isu manajemen sampah dapat menjadi potensi penentuan program Third Place yang dapat mereduksi permasalahan pada kawasan?

\section{Tujuan}

a. Menjadi ruang singgah dan wadah interaksi yang bersifat rekreatif antar masyarakat lokal dan komuter Kelurahan Manggarai.

b. Mengangkat isu lingkungan sebagai sarana/wadah dalam interaksi sosial sekaligus memberikan edukasi nonformal mengenai manajemen sampah pada kawasan.

a. Meningkatkan kualitas hidup masyarakat setempat dengan menerapkan budaya peduli lingkungan dalam program dan fungsi proyek.

\section{KAJIAN LITERATUR}

\section{Rekreasi}

Rekreasi (bahasa Latin, re-creare) secara harfiah berarti 'membuat ulang', adalah kegiatan yang dilakukan untuk penyegaran kembali jasmani dan rohani seseorang. Rekreasi merupakan aktivitas yang dilakukan oleh orang-orang secara sengaja sebagai kesenangan atau untuk kepuasan, umumnya dalam waktu senggang (leasuretime). Leasure berasal dari kata "licere" (latin) yang berarti diperkenankan menikmati saat-saat yang bebas dari kegiatan rutin untuk memulihkan atau menyegarkan kembali. "Kebutuhan melakukan sesuatu untuk rekreasi" adalah elemen penting bagi tubuh dan psikologi manusia (Daniels, 1995). Menurut kamus bahasa Inggris, kata rekreasi merupakan terjemahan dari bahasa Inggris yang berasal dari kata benda recreation yang berarti hal penciptaan kembali, hal bersuka ria, dan hal melepas lelah. Menurut Bovy dan Lawson (1997) ada beberapa hal yang menjadi faktor dalam mempengaruhi rekreasi antara lain :

a. Faktor sosial ekonomi,

b. Faktor jenis kelamin,

c. Faktor ketersediaan waktu luang,

d. Faktor pranata,

e. Faktor perubahan teknologi,

Dari penjelasan yang ada dapat diambil kesimpulan bahwa rekreasi adalah aktivitas yang dilakukan pada waktu senggang dengan tujuan untuk membentuk, meningkatkan kembali kesegaran fisik, mental, dan pikiran (baik secara individual maupun secara kelompok) yang hilang akibat aktivitas rutin sehari-hari dengan cara mencari kesenangan, hiburan dan kesibukan yang berbeda dan dapat memberikan kepuasan dan kegembiraan yang ditujukan bagi kepuasan lahir dan batin manusia.

\section{Lokakarya}

Menurut KBBI, lokakarya merupakan pertemuan antara para ahli (pakar) untuk membahas masalah praktis atau yang bersangkutan dengan pelaksanaan dalam bidang keahliannya, yang dapat diartikan juga sebagai sanggar kerja. Sanggar kerja adalah pertemuan untuk 
mengadakan tukar pikiran (pembahasan, pengolahan, dan sebagainya) tentang suatu bidang ilmu atau bidang kegiatan tertentu. Lokakarya / sanggar merupakan pendidikan nonformal yang mencakup seluruh proses dari awal hingga akhir yaitu mencakup proses pengenalan (biasanya melalui pelatihan singkat), pembelajaran, penciptaan atau membuat karya, dan produksi. contoh: pembelajaran melukis, membuat karya lukis kemudian pameran, penjualan/pelelangan semua dilakukan di dalam sanggar.

\section{Pengelolaan Sampah}

Menurut Azwar (1990: 53) sampah adalah sesuatu yang tidak dipergunakan lagi, yang tidak dapat dipakai lagi, yang tidak disenangi dan harus dibuang, maka sampah tentu saja harus dikelola dengan sebaik-baiknya. Kodoatie (2003) mendefinisikan sampah adalah limbah atau buangan yang bersifat padat atau setengah padat, yang merupakan hasil sampingan dari kegiatan perkotaan atau siklus kehidupan manusia, hewan maupun tumbuh-tumbuhan. Sampah dalam ilmu kesehatan lingkungan (refuse) sebenarnya hanya sebagian dari benda atau hal-hal yang dipandang tidak digunakan, tidak dipakai, tidak disenangi atau harus dibuang, sehingga tidak menganggu kelangsungan hidup. Pengelolaan sampah adalah pengumpulan, pengangkutan, pengolahan, mendaur ulang dari material sampah. Kalimat ini biasanya mengacu pada material sampah yang dihasilkan dari kegiatan manusia, dan biasanya dikelola untuk mengurangi dampaknya terhadap kesehatan, lingkungan, atau estetika. Pengelolaan sampah juga dilakukan untuk memulihkan sumber daya alam (resources recovery). Pengelolaan sampah bisa melibatkan zat padat, cair, gas, atau radioaktif dengan metode dan keterampilan khusus untuk masing-masing jenis zat. Terkait pengelolaan pada praktiknya, penanganan sampah dijabarkan menjadi Reduce, Reuse, Recycle, Recovery, dan Disposal.

\section{Architecture Third Place}

"Architecture as a third place" atau disebut juga sebagai ruang ketiga merupakan ruang antara yang diperuntukan untuk relaksasi sekaligus sebagai tempat untuk bersosialisasi dengan masyarakat lainnya sebagai bentuk "pelarian" dari tempat pertama yang biasa kita sebut rumah dan juga tempat kedua yang kita kenal sebagai tempat kerja. Menurut Oldenburg (1989) karakteristik Third Place meliputi, On Neutral Ground, The Third Place as Leveler, Conversation is the Main Activity, Accessibility and Accommodation, The Regulars, A Low Profile, The Mood is Playful, A Home Away from Home.

\section{METODE}

\section{Pengumpulan dan Pengolahan Data}

a. Studi Literatur, dengan cara studi dari berbagai buku, dokumentasi, jurnal dan publikasi seperti Badan Pusat Statistik yang dilakukan untuk memperoleh fakta, data, serta teori yang mendukung pemahaman Third Place sebagai dasar pemikiran untuk memperoleh solusi yang dapat dipertanggungjawabkan.

b. Observasi Lapangan, tinjauan langsung pada kawasan Kelurahan Manggarai untuk merasakan secara nyata keadaan serta mendokumentasikan kegiatan dan fenomena yang terjadi di lapangan.

c. Wawancara dan Diskusi, interaksi dengan warga sebagai subjek yang berkegiatan di kawasan Kelurahan Manggarai dengan cara interaksi dua arah terhadap kebutuhan maupun keresahan yang dialami disana.

\section{Analisis dan Desain Kontekstual}

Arsitektur kontekstual, atau dikenal sebagai Contextualism adalah pendekatan filosofis dalam teori arsitektur yang mengacu pada perancangan desain dengan merespon karakteristik literal dan abstrak dari lingkungan. Arsitektur kontekstual berlawanan dengan arsitektur modern, yang bersifat karakteristik dan nilai-nilai mereka sendiri pada lingkungan buatan. Pada masa 
postmodern, arsitek O.M. Ungers membuat sebuah abstrak diagram mengenai gambaran dasar lingkungan sekitar (sudut atap, axis jendela, tekstur, dsb) dan menerapkan rekonstruksi komposisi elemen yang mirip pada rancangannya tahun 1978 (Jormakka, 2008).

Metode kontekstual ditujukan dalam tahap perancangan dengan menggunakan elemen, tipologi, dan axis bangunan sekitar dalam menerapkan bentuk, pembagian area fungsi, dan tata letak ruang pada proyek. Arus gerak dari pejalan kaki diterapkan sebagai patokan gerak jalur pedestrian dalam merespon fungsi dan kebutuhan kawasan sekitar. Dalam pembahasannya, elemen kontekstual dibagi menjadi tiga, yaitu Form (bentuk), Color (warna), dan Texture (tekstur).

\section{DISKUSI DAN HASIL}

\section{Analisis Lokasi}

Kelurahan Manggarai terletak di Kecamatan Tebet, Jakarta Selatan dan dikenal karena terdapat pintu air Kali Ciliwung dan sebuah Stasiun kereta api penting. Stasiun Manggarai dikelilingi oleh bangunan yang didominasi oleh perumahan KB rendah dan beberapa pertokoan.
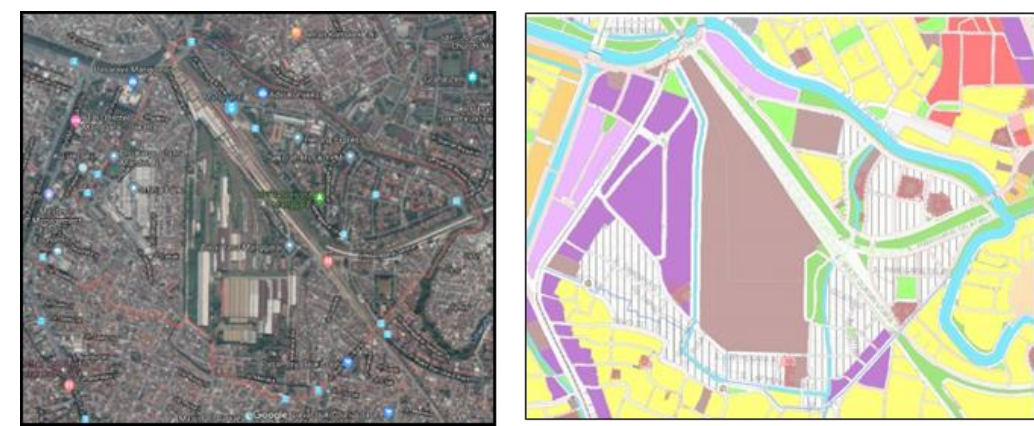

Gambar 1. RTRW Kelurahan Manggarai

Sumber: http:// maps.google.com \& https://jakartasatu.jakarta.go.id, Feb 2020

Kelurahan Manggarai merupakan kawasan yang cocok untuk menerapkan ruang ketiga dengan berbasiskan akses dan akomodasi pengguna hunian padat, dilihat dari banyaknya rumah penduduk disekitar stasiun dan sepanjang sungai.

\section{1.}

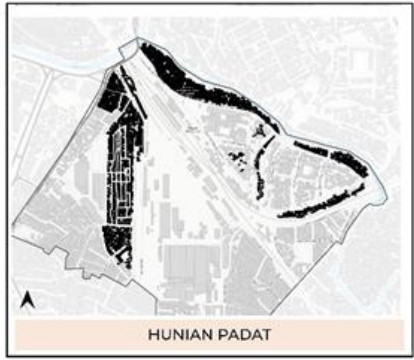

3.

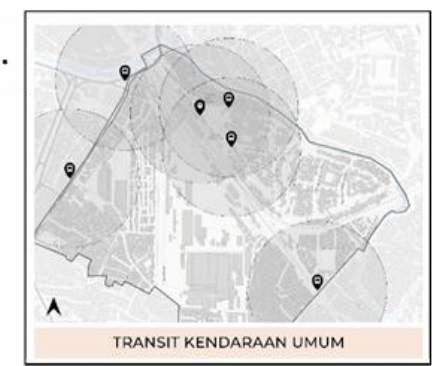

2.

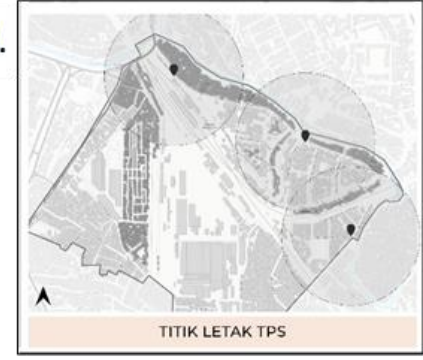

4.

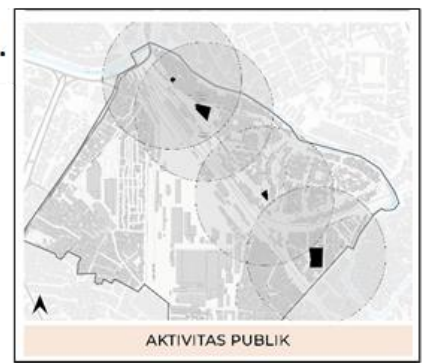

Gambar 2. Mapping Kelurahan Manggarai Sumber: Penulis, 2020 
a. Hunian Padat, Penyebaran hunian padat mayoritas berada pada sepanjang pinggiran sungai dan sekitar area stasiun. Area hunian umumnya dihubungkan dengan jalan gang yang hanya dapat diakses oleh pejalan kaki dan sepeda motor.

b. Titik Letak TPS, TPS adalah Tempat Penampungan Sementara sampah sebelum dibawa ke TPA. Titik radius berjarak sejauh $300 \mathrm{~m}$, radius ini mencangkup pemasukan sampah dari hunian sekitar terutama pada hunian padat yang tidak memiliki penampungan sampah pada tiap huniannya.

c. Transit Kendaraan Umum, Manggarai dikenal sebagai kawasan perlintasan transit bagi komuter kendaraan umum Transjakarta dan KRL. Third Place sebagai wadah interaksi dan rekreasi warga sekitar juga merespon sirkulasi dan akses para komuter yang berpindah tempat dari transit ke transit lainnya agar memudahkan akomodasi para "regulars" maupun pengunjung baru.

d. Aktivitas Publik, Area publik pada warga terdiri dari lapangan bersama, RPTRA, dan teras kantor kepengurusan RW. Keramaian publik dijadikan sebagai patokan lokasi untuk proyek agar memudahkan pencapaian warga serta mendukung kegiatan rekreasi dan aktivitas bersama.

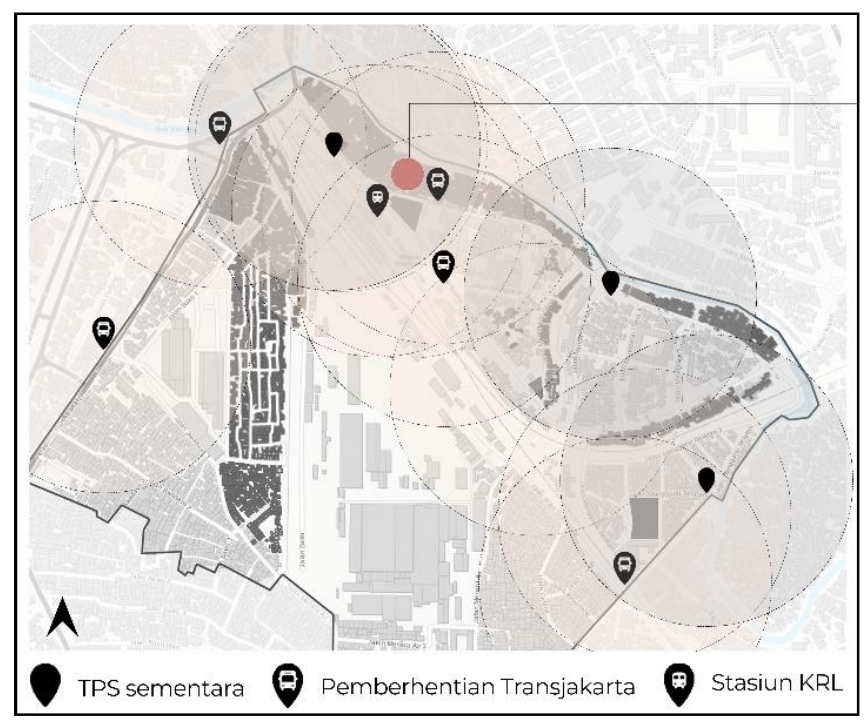

Gambar 3. Titik Penempatan Lokasi Proyek Sumber: Penulis, 2020

Jadi, lokasi tapak ditentukan berdasarkan respon hunian padat terbanyak yang tercakup dalam radius TPS serta sirkulasi komuter dari titik-titik transit yang ada. Lokasi tapak juga merespon adanya ruang publik sebagai pusat kegiatan rekreasi warga sehingga proyek nantinya dapat saling melengkapi kebutuhan. Penentuan tapak juga berdasarkan RTRW kawasan dimana zonasi yang berlaku adalah K.3. 

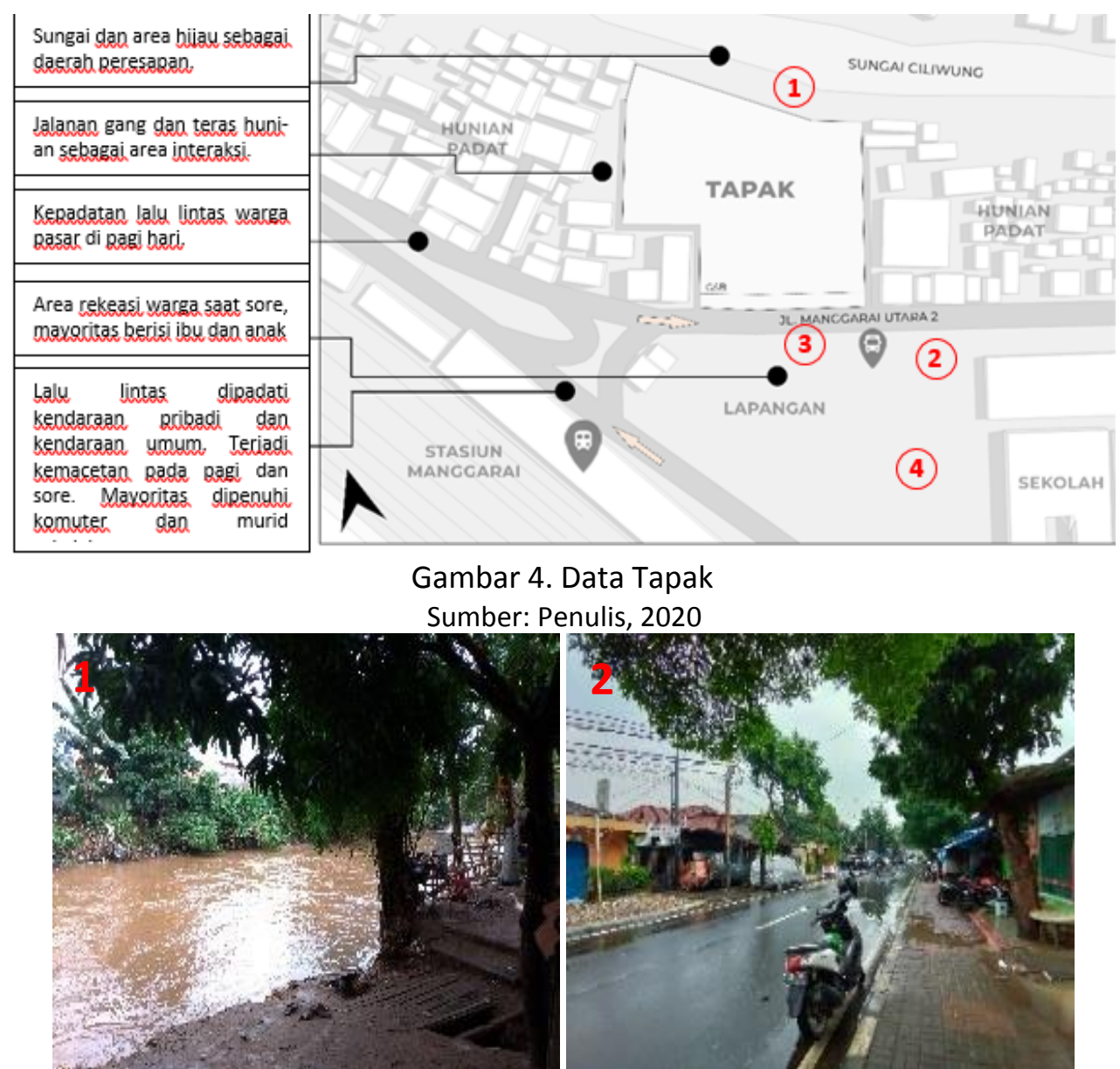

Gambar 4. Data Tapak

Penulis, 2020
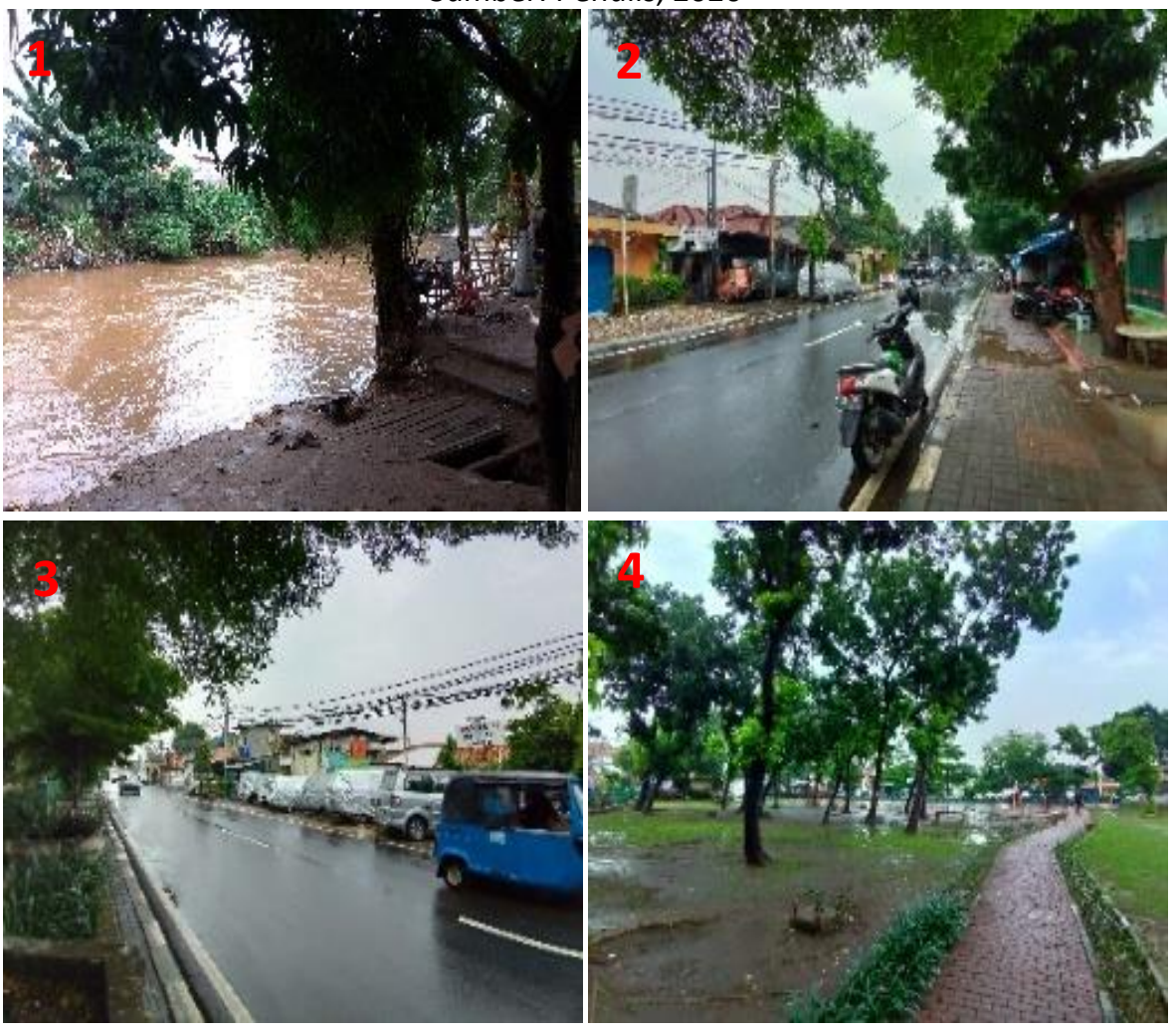

Gambar 5. Kondisi Tapak Sekitar

Sumber: Penulis, 2020

Tapak berada pada Jl. Manggarai Utara 2, diantara hunian padat yang cenderung memiliki ketinggian yang sama (2 Tingkat) dan dibatasi oleh Sungai Ciliwung pada arah utara. Batas tapak ditentukan dari jalan (path) untuk sirkulasi warga masuk dan keluar hunian. Tapak berdekatan dengan tempat transit kendaraan umum (TJ \& Stasiun) serta berseberangan dengan area publik terbuka lapangan futsal dan basket sebagai area berkumpul warga.

\section{Konsep Perancangan}

Dari survey lapangan, data diolah kemudian dianalisa dan digunakan untuk menjadi acuan awal mendesain. Gubahan massa diproses dengan metode kontekstual yang merespon potensi, aktivitas, dan kebiasaan warga setempat. Berikut gambar-gambar yang dijadikan sebagai representasi dari masing-masing prosesnya. 


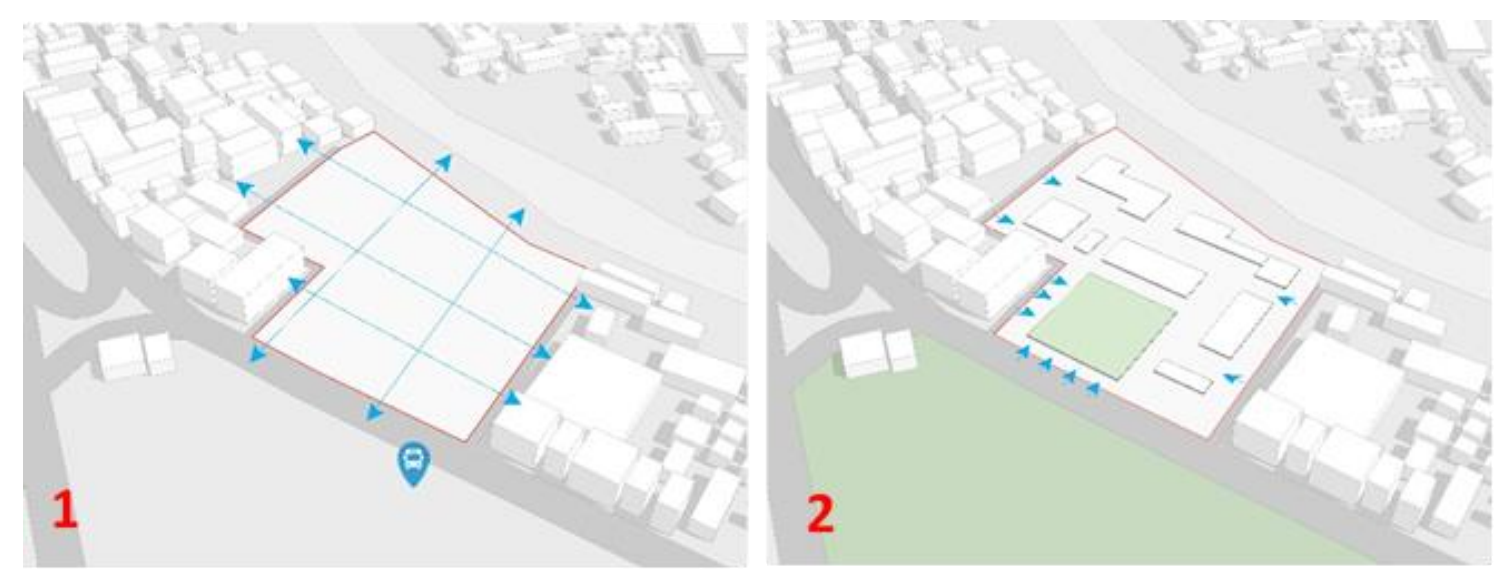

Gambar 6. Transformasi Massa 1 dan 2

Sumber: Penulis, 2020

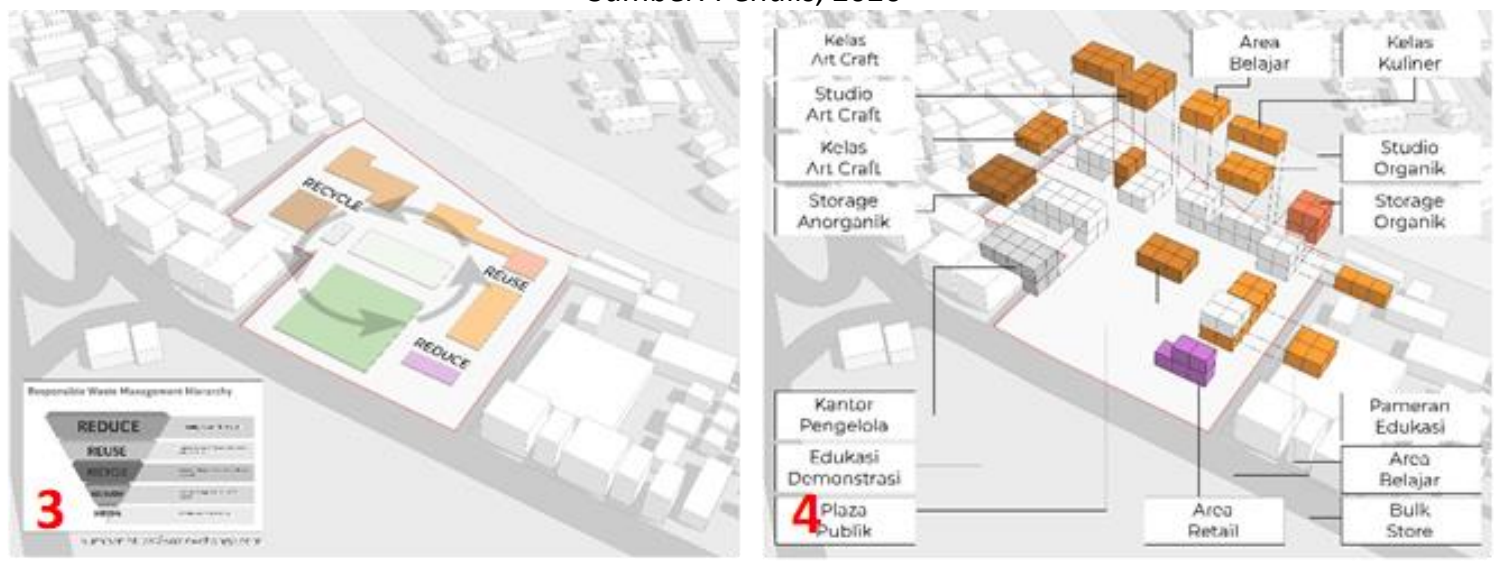

Gambar 7. Transformasi Massa 3 dan 4

Sumber: Penulis, 2020

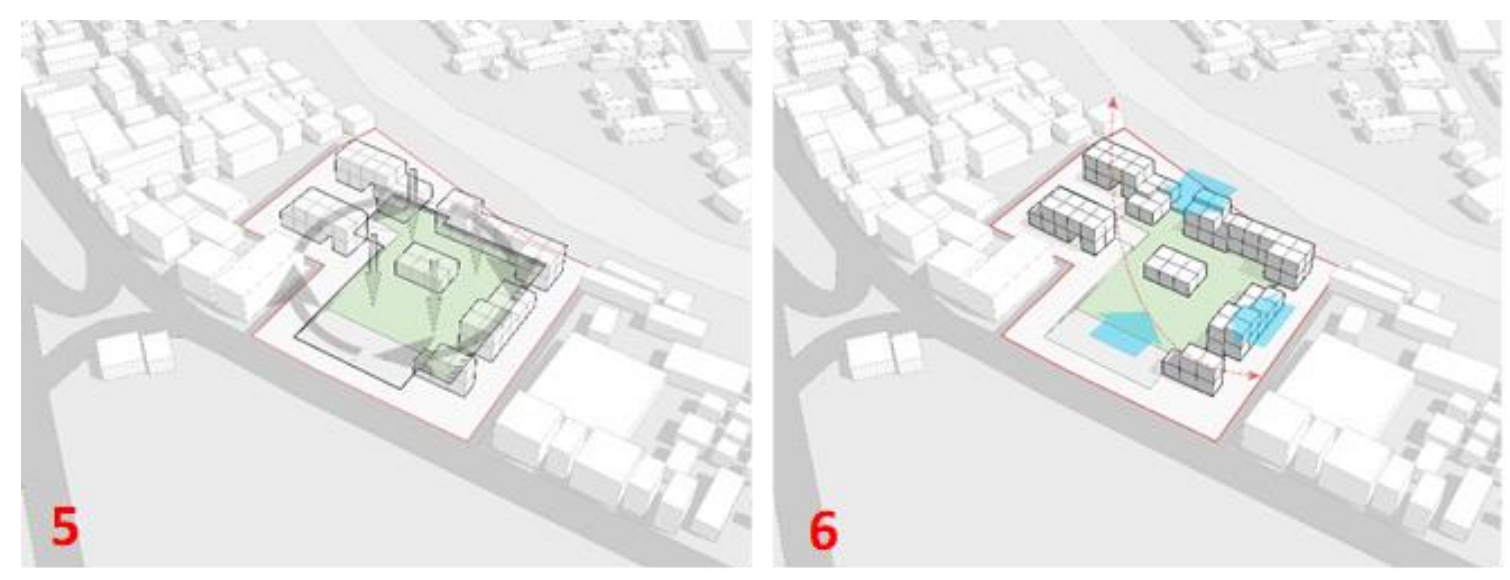

Gambar 8. Transformasi Massa 5 dan 6

Sumber: Penulis, 2020 


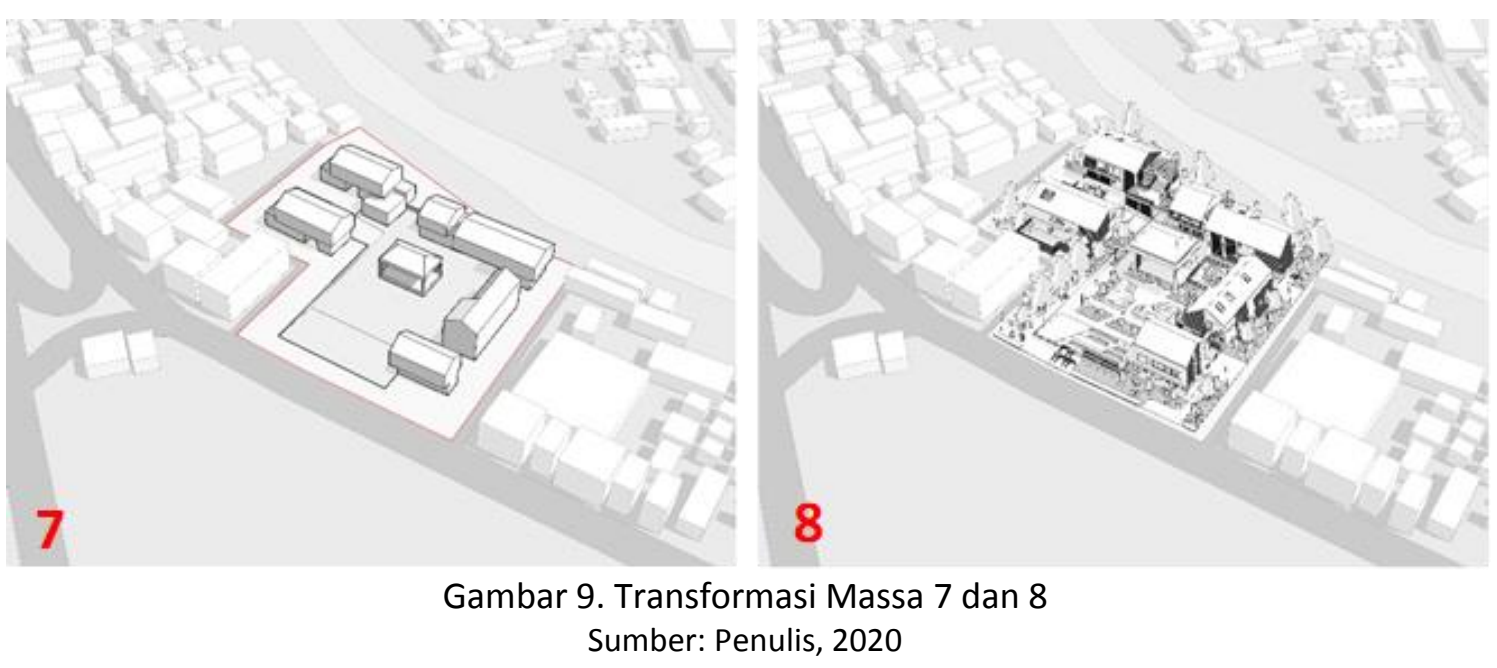

No. 1. Akses dan koneksi, Tapak yang menghubungkan dua area hunian padat. Memberi kemungkinan akses dan koneksi yang terjadi dilihat dari jalan sirkulasi pada kedua area hunian padat. Tapak menjadi perantara yang menghubungkan warga sekitar serta jalan utama.

No. 2. Ruang publik, Akses dan koneksi dijadikan sebagai entrance masuk menuju tapak. Merespon ruang publik dengan meneruskan area lapangan diseberang tapak. Akses yang melintas pada tapak dijadikan sebagai patokan bentuk zonasi program.

No. 3. Zonasi program, Waste Management Hierarchy menjadi dasar zonasi yang disesuaikan dengan usulan program utama.

No. 4. Susunan massa, Susunan program berdasarkan satuan modul $4 \times 4 \mathrm{~m}$ yang dijadikan patokan untuk struktur bentang beton. Dengan ukuran $16 \mathrm{~m} 2$ diperkirakan dapat menampung sebanyak 6 orang dengan standar satuan $2.4 \mathrm{~m} 2$ untuk kegiatan sanggar (studio).

No. 5. Plaza publik, Area central (Plaza) pada tapak ditekan kebawah sebagai pembatas buffer dengan jalan raya dan area interaksi yang menyatukan semua program. Menjadi tempat bertemu warga dan komunitas, bertukar ilmu dan pikirian, area bermain atau berekspresi dengan program yang disajikan.

No. 6. View, Penggeseran massa ke bawah menciptakan ruang balkon yang difungsikan sebagai area berkumpul dan melihat ke arah plaza. Susunan dari massa membentuk cekukan yang memfokuskan pandangan ke area tengah plaza.

No. 7. Susunan atap, Massa pada tingkat dua diperlebar untuk menciptakan teritis pada lantai satu. Bentuk atap merespon dari iklim tropis kawasan serta bentuk pelana untuk membaur dengan hunian sekitar. Area central diberi atap pada panggung demonstrasi sebagai orientasi utama dan massa yang menonjol pada proyek.

No. 8. Vegetasi dan servis, Plaza dan akses menuju tapak diberi pengerasan dan ruang hijau, pada muka tapak diberi parkiran sepeda serta drop off yang berdekatan dengan transit TJ. Area plaza publik dapat difungsikan sebagai pameran karya hasil studio, penyuluhan edukasi mengenai waste, area diskusi, serta area bermain anak-anak.

Penyebaran massa dengan adanya jarak dan ruang hijau antara massa difungsikan agar tidak menambah kesan padat pada kawasan sekitar. Pembagian zonasi dan ruang secara keseluruhan dibagi menjadi dua, pada lantai satu difungsikan sebagai wadah interaksi dan rekreasi antar pengguna yang sekaligus mengenalkan warga sekitar tentang budaya lingkungan dan manajemen sampah dari fungsi program yang disediakan, pada lantai kedua difungsikan sebagai wadah edukasi dan pendidikan nonformal bagi warga setempat untuk lebih mengenal proses lanjutan dari manajemen sampah. 


\section{Program Kegiatan}

Program bangunan yang diusulkan berdasarkan dengan runtutan kegiatan dalam melakukan pengelolaan manajemen sampah (Reduce, Reuse, Recycle), yang pada setiap penjabaran poinnya diwakilkan oleh fungsi program ruang yang mendukung sehingga setiap program yang diusulkan secara langsung ataupun tidak langsung dapat memberikan pengguna edukasi atau ilmu mengenai manajemen sampah pada kawasan. Dari gambaran besar kegiatan pada proyek dapat dijabarkan kembali lebih spesifik menjadi program ruang utama pada proyek ini.

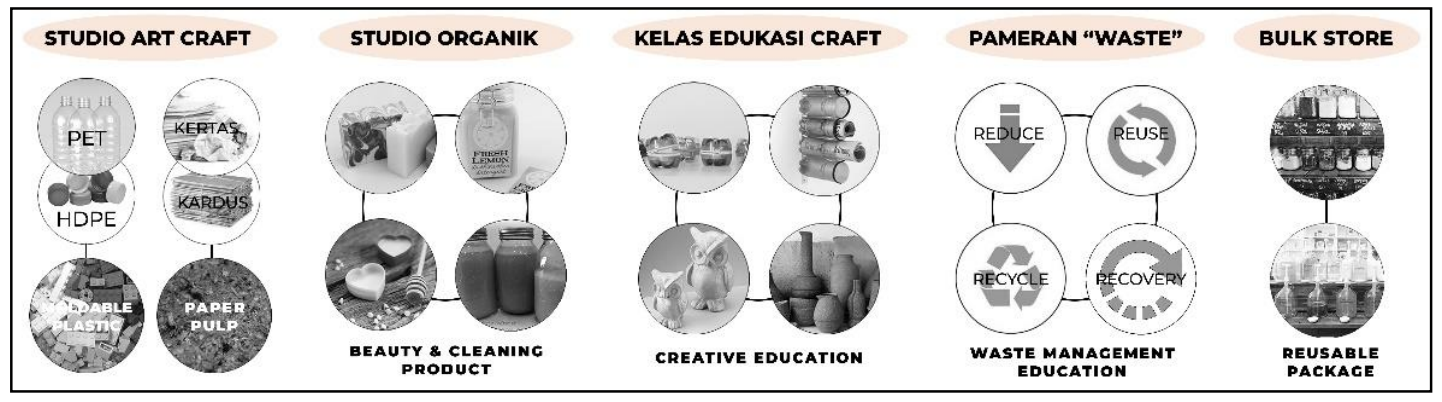

Gambar 10. Penjabaran Program Utama

Sumber: Penulis, 2020

a. Studio Art Craft, sanggar seni dengan memanfaatkan sampah plastik dan kertas yang didaur ulang kembali menjadi bahan mentah untuk media kerajinan seni.

b. Studio Organik, sanggar untuk pembuatan produk rumahan yang ramah lingkungan, dengan tujuan untuk mengurangi penggunaan sampah pembungkus sekali pakai.

c. Kelas Edukasi, sanggar pendidikan nonformal berupa kerajinan seni, kelas kuliner, perpustakaan, dan area belajar sebagai respon kebutuhan pendidikan bagi warga yang kurang mampu.

d. Pameran "Waste", pameran edukasi sebagai media penyuluhan tentang manajemen sampah sekaligus sebagai wadah untuk menampilkan hasil karya seni dari sanggar/studio.

e. Bulk Store, Area jual beli produk hasil olahan studio organik dengan menerapkan sistem reusable container.

Dengan adanya program yang diusulkan ini diharapkan masyarakat hunian padat sekitar dapat merasakan adanya ruang sosial yang terpadu untuk berinteraksi dan berekreasi antar sesama dalam bentuk sarana edukasi nonformal yang kreatif serta belajar mengenai manajemen sampah yang dapat menambah kualitas hidup masyarakat dan menerapkan budaya baru untuk lebih peduli terhadap lingkungan.

Tabel 1. Program Ruang Bangunan

\begin{tabular}{|l|c|c|c|c|c|}
\hline \multicolumn{7}{|c|}{ PROGRAM RUANG } \\
\hline \multicolumn{7}{|c|}{ RUANG } & KAPASITAS & STANDART (M2/ORG) & SUMBER & JUMLAH & LUAS (M2) \\
\hline \multicolumn{7}{|c|}{ RUANG STUDIO DAUR ULANG } \\
\hline Studio Art \& Craft & 50 & 2.4 & NAD & 1 & 120 \\
\hline Kelas Art \& Craft & 20 & 2.4 & NAD & 2 & 96 \\
\hline R. Finishing Produk & 25 & 2.4 & NAD & 1 & 60 \\
\hline R. Pantry & 4 & 4 & NAD & 1 & 16 \\
\hline R. Penyimpanan Bahan & - & - & NAD & 1 & 120 \\
\hline R. Pengolahan Bahan & 30 & 2.4 & NAD & 1 & 72 \\
\hline Toilet & 10 & 5.5 & NAD & 1 & 55 \\
\hline \multicolumn{7}{|l|}{ Total + Sirkulasi (30\% dari luas) } & & $688 \mathrm{m2}$ \\
\hline
\end{tabular}




\begin{tabular}{|c|c|c|c|c|c|}
\hline \multicolumn{6}{|c|}{ RUANG STUDIO ORGANIK } \\
\hline R. Penyimpanan Bahan & - & - & NAD & 1 & 120 \\
\hline Studio Organik & 25 & 2.4 & NAD & 1 & 60 \\
\hline Kelas Kuliner & 20 & 2.4 & NAD & 1 & 48 \\
\hline Bulk Store & 47 & 4 & NAD & 1 & 190 \\
\hline R. Pantry & 4 & 4 & NAD & 1 & 16 \\
\hline Toilet & 5 & 5.5 & NAD & 1 & 27.5 \\
\hline \multicolumn{5}{|c|}{ Total + Sirkulasi (30\% dari luas) } & $600 \mathrm{~m} 2$ \\
\hline \multicolumn{6}{|c|}{ RUANG EDUKASI } \\
\hline R. Pameran Waste & 20 & 5 & NAD & 1 & 100 \\
\hline Perpustakaan & 36 & 2.5 & NAD & 1 & 90 \\
\hline R. Audio Visual & 20 & 2 & NAD & 1 & 40 \\
\hline A. Belajar & 20 & 2 & NAD & 1 & 40 \\
\hline R. Komunal Outdoor & 20 & 2.4 & NAD & 3 & 144 \\
\hline \multicolumn{5}{|c|}{ Total + Sirkulasi (30\% dari luas) } & $538 \mathrm{~m} 2$ \\
\hline \multicolumn{6}{|c|}{ KANTOR PENGELOLA } \\
\hline Resepsionis & UNIT & 45 & TSS & 1 & 45 \\
\hline R. Manager & 2 & 4.46 & NAD & 1 & 10 \\
\hline R. Staff Pengelola & 5 & 4.46 & NAD & 1 & 25 \\
\hline R. Rapat & 5 & 2 & NAD & 1 & 10 \\
\hline R. Pantry & 4 & 4 & NAD & 1 & 16 \\
\hline Toilet & 1 & 5.5 & NAD & 1 & 5.5 \\
\hline \multicolumn{5}{|c|}{ Total + Sirkulasi (30\% dari luas) } & $145 \mathrm{~m} 2$ \\
\hline \multicolumn{6}{|c|}{ RUANG PELENGKAP \& SERVIS } \\
\hline A. Plaza Publik & 100 & 3 & NAD & 1 & 300 \\
\hline A. Demonstrasi & 30 & 2.4 & NAD & 1 & 80 \\
\hline R. Trafo \& Panel & 1 & 12 & ASS & 1 & 12 \\
\hline Café Retail & - & - & - & 1 & 100 \\
\hline Parkiran Sepeda & 1 & 0.675 & SRP & 24 & 16 \\
\hline Loading Dock & 10 & 1.6 & NAD & 1 & 16 \\
\hline Parkiran Servis & 1 & 1.5 & SRP & 1 & 90 \\
\hline \multicolumn{5}{|c|}{ Total + Sirkulasi (30\% dari luas) } & $800 \mathrm{~m} 2$ \\
\hline \multicolumn{5}{|c|}{ TOTAL LUAS KESELURUHAN } & $2771 \mathrm{~m} 2$ \\
\hline
\end{tabular}

Sumber: Penulis, 2020

\section{Penggunaan Material Bangunan}

Penggunaan material bangunan mayoritas menggunakan finishing beton yang dipoles halus untuk memberikan kesan material yang sederhana. Warna abu-abu yang tidak rata dan tidak sempurna memberikan kealamian dari material dan mudah dipadukan dengan material dan warna lainnya. Sebagai aksen pada material digunakan kisi-kisi kayu yang dipernis untuk menonjolkan warna alaminya, ekspos kayu pada bangunan memperkuat kesan rustic, menciptakan sensasi alami, serta penyatuan dengan lingkungan, selain kayu digunakan juga kisi-kisi besi dengan warna hitam yang netral untuk memberikan kesan perbedaan material tanpa merusak kesan kesederhanaan dari bangunan. 

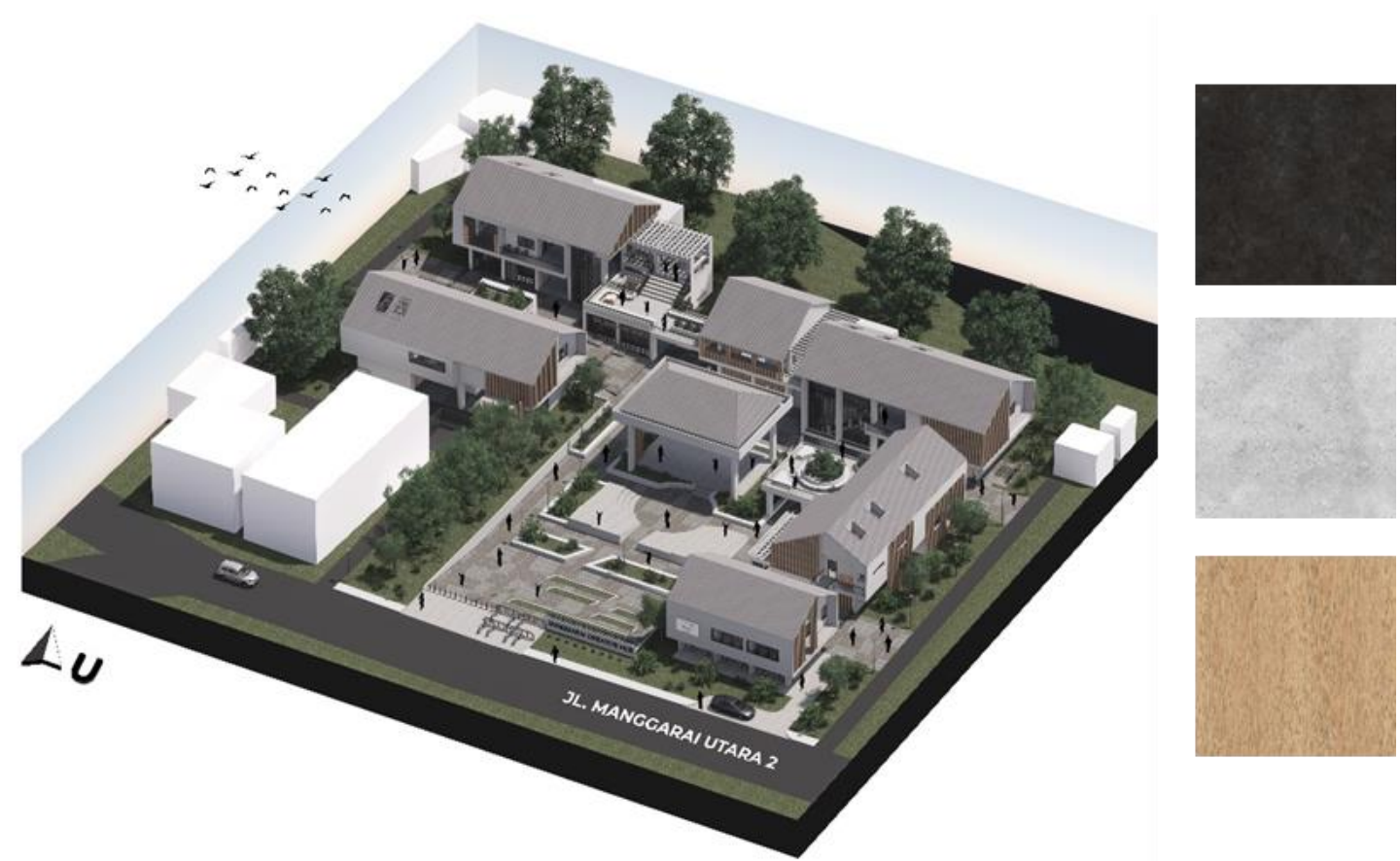

Gambar 11. Aksonometri Bangunan

Sumber: Penulis, 2020

Penggunaan material, warna, serta tekstur dari bangunan ditujukan agar bangunan tidak terlalu menonjol dari lingkungannya (low profile), penggunaan material pada bangunan ini diharapakan dapat membaur dan tidak menambah kesesakan pada kawasan hunian padat. Kisi kayu dan rangka besi selain menjadi aksen material pada proyek, berfungsi juga sebagai partisi yang dapat meneruskan view antar sesama ruang dan juga dapat difungsikan sebagai media pameran dan wadah untuk menampilkan hasil karya seni dari sanggar/studio.
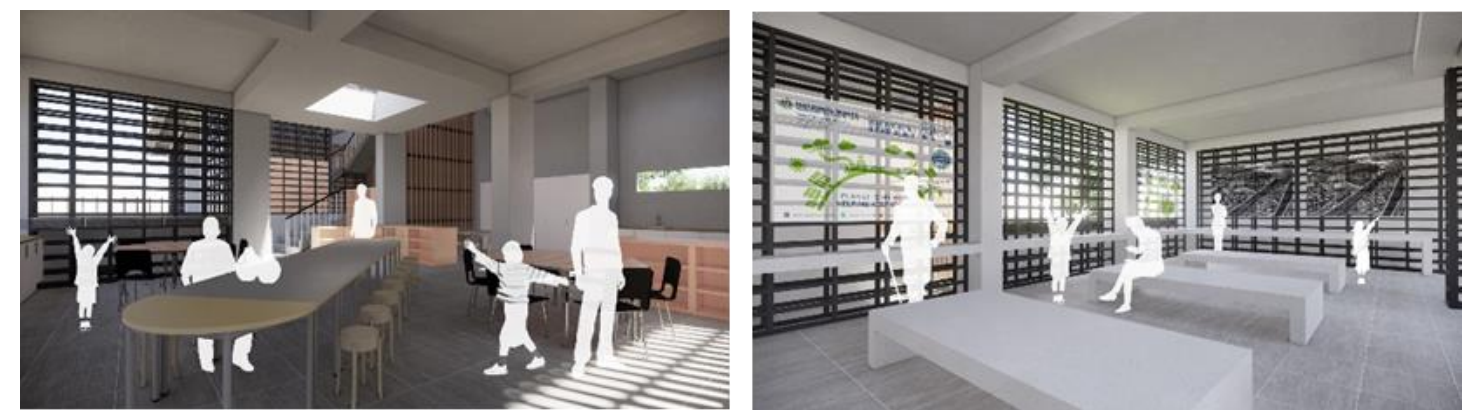

Gambar 12. Penggunaan Partisi Kayu dan Besi

Sumber: Penulis, 2020

\section{Sirkulasi Udara dan Pencahayaan Alami}

Bangunan memiliki berbagai bukaan untuk masuknya cahaya serta udara alami ke dalam ruang dengan memanfaatkan partisi kisi-kisi kayu dan rangka besi. Pada penutup atap juga terdapat beberapa titik skylight yang berfungsi memasukan cahaya matahari secara alami ke fungsi-fungsi ruang utama. 


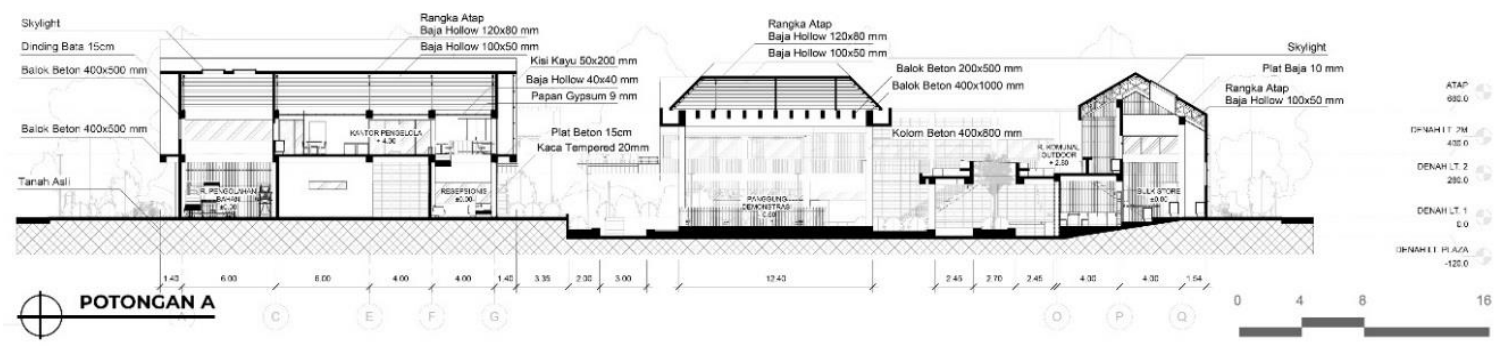

Gambar 13. Titik Skylight Pada Potongan Sumber: Penulis, 2020

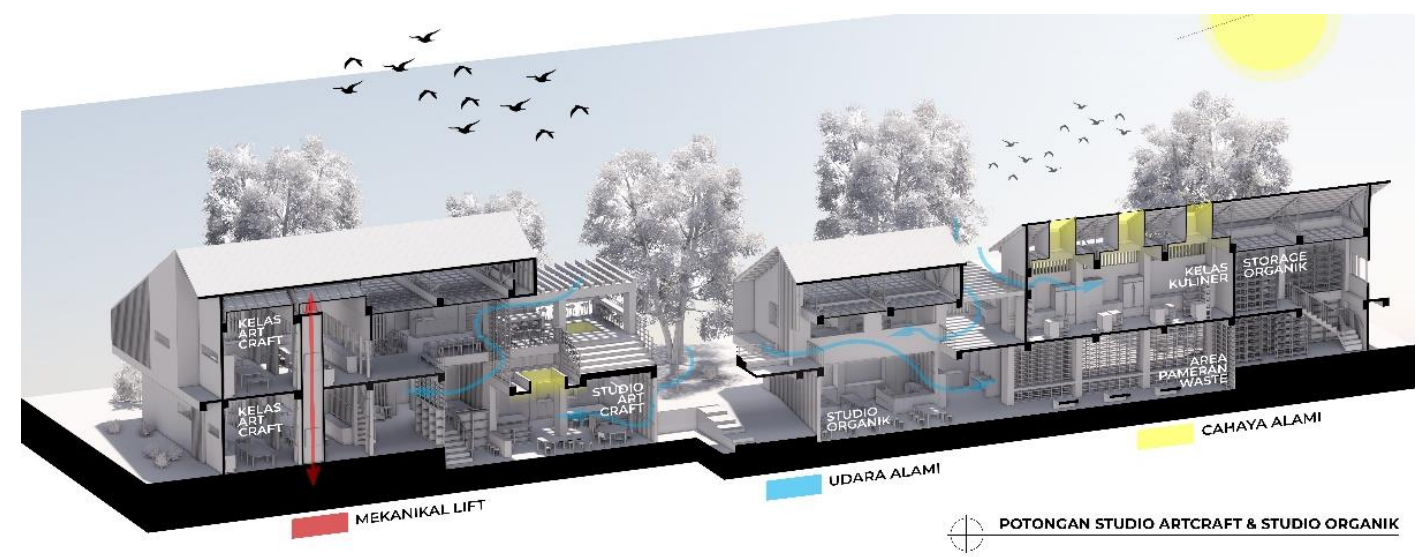

Gambar 14. Potongan 3D Bangunan

Sumber: Penulis, 2020

Respon dari pencahayaan alami dan sirkulasi udara sangat dibutuhkan oleh fungsi ruang pada proyek terutama pada kegiatan indoor yang membutuhkan pencahayaan dalam melakukan kegiatan karya yang bersifat presisi dan detail seperti kelas kuliner dan kelas art craft.
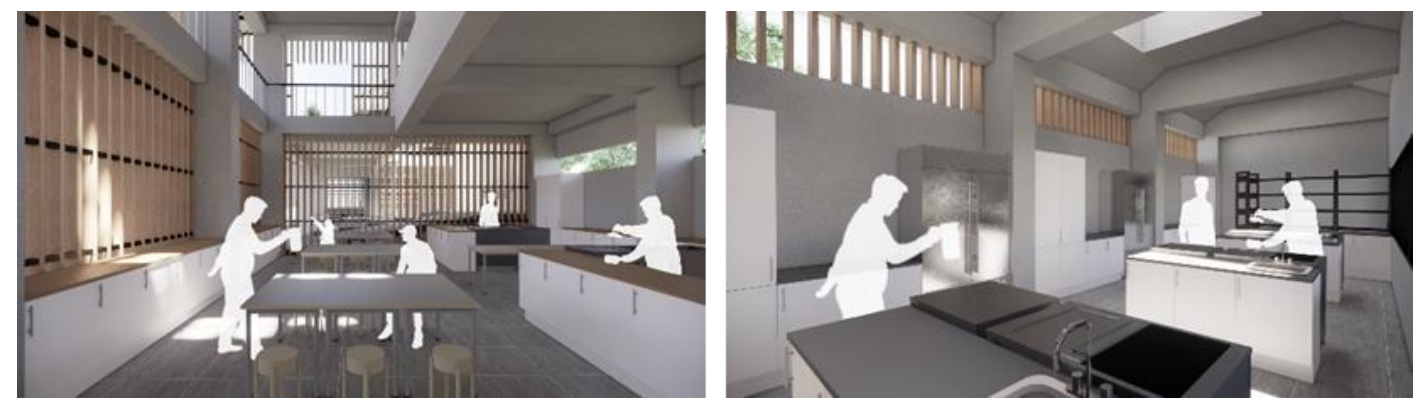

Gambar 15. Penggunaan Kisi Kayu Sebagai Sirkulasi Udara

Sumber: Penulis, 2020
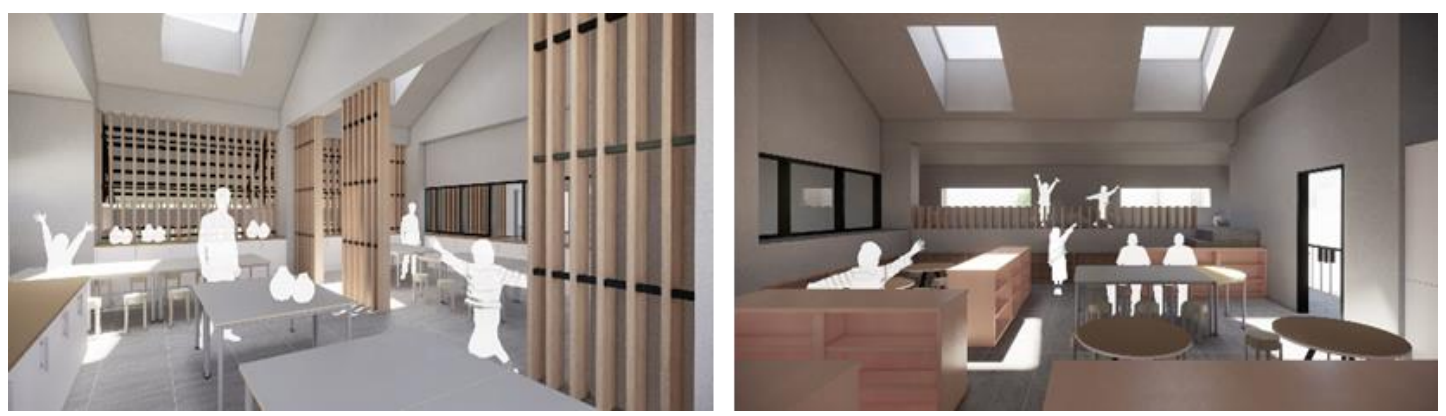

Gambar 16. Penggunaan Skylight Cahaya Alami

Sumber: Penulis, 2020 


\section{Gambar Kerja}

Penjabaran karakteristik dari third place dapat dilihat dalam respon desain, bangunan sebagai ruang singgah antara tempat tinggal dan tempat kerja dengan suasana yang menyenangkan untuk merelaksasi warga perkotaan, merespon kebutuhan warga lokal dan komuter kawasan, menjadi tempat bertemunya pengguna dari latar belakang dan karakter yang berbeda, menyatukan interaksi pengguna dengan kegiatan rekreasi seni, bersifat permeable dalam arti memungkinkan entrance dari berbagai sisi dan tembusan antar massanya, bersifat kontekstual dengan karakter hunian padat dengan tujuan memberikan suasana yang menyerupai lingkungan hunian.

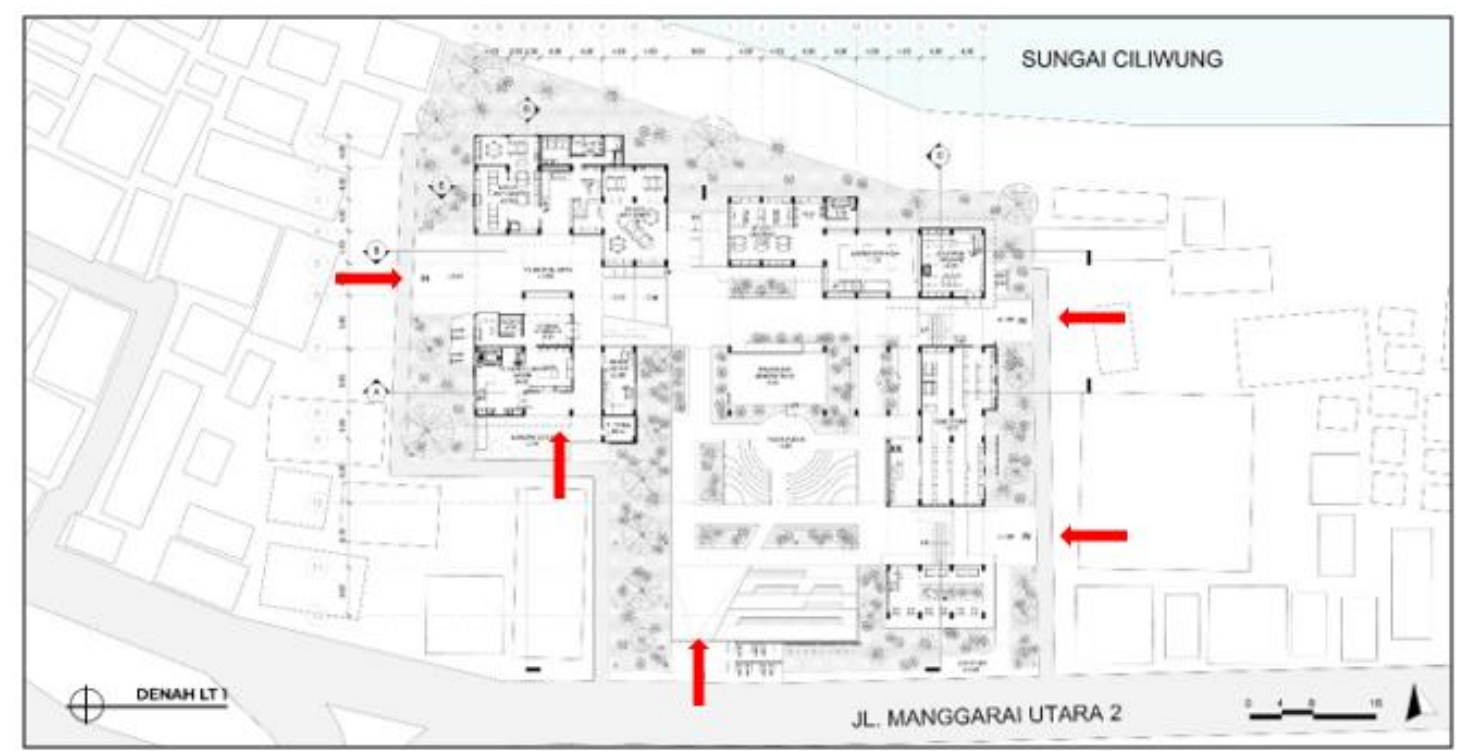

Gambar 17. Akses Masuk Denah Lantai 1 Sumber: Penulis, 2020

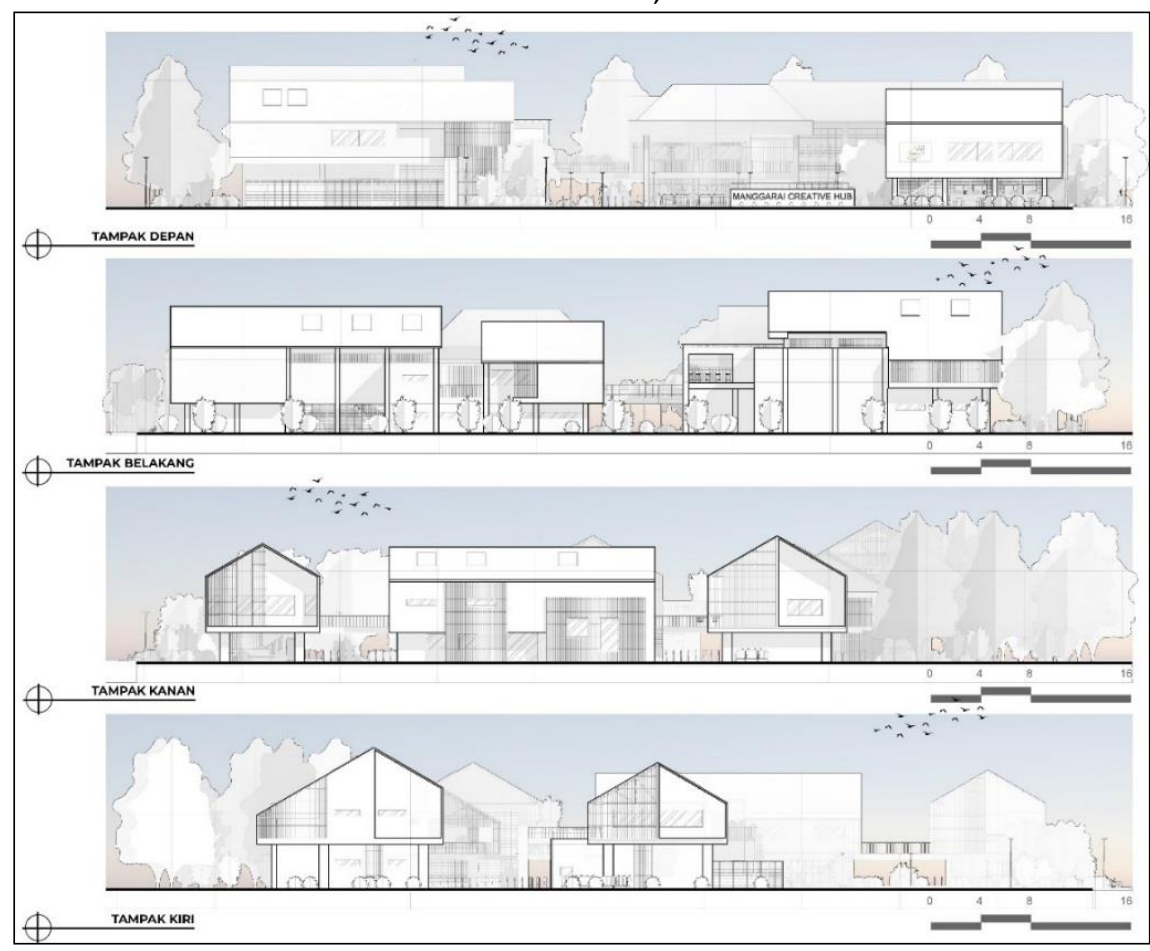

Gambar 18. Tampak Bangunan

Sumber: Penulis, 2020 


\section{KESIMPULAN DAN SARAN \\ Kesimpulan}

Kebutuhan sosial dari masyarakat pada kawasan hunian padat di Manggarai dapat diwadahi dengan adanya fungsi third place yang memberikan fungsi program rekreasi dan relaksasi untuk melepas kejenuhan warga permukiman padat. Dalam rangka menciptakan ruang dengan mengangkat isu manajemen sampah, studio art craft dengan media daur ulang sampah, studio organik sebagai wadah produksi kebutuhan pokok, serta program fungsi edukasi nonformal lainnya dapat mereduksi penyebaran dan penumpukan sampah hunian padat sekaligus memberikan pandangan baru mengenai budaya ramah lingkungan pada kawasan hunian padat.

\section{Saran}

Penulis hendak memberikan saran yang sekiranya dapat berguna bagi penelitian selanjutnya yaitu mempelajari lebih dalam mengenai lokalitas dan karakter dari kawasan maupun warga hunian padat. Pengembangan selanjutnya dapat diperdalam lagi dengan metode studi kasus pada proyek yang serupa dengan isu potensial manajemen sampah dan dengan penelitian kuantitatif yaitu melakukan wawancara lebih dalam terhadap publik mengenai isu dan potensial kawasan hunian padat.

\section{REFERENSI}

Azwar, A. (1990). Pengantar Ilmu Lingkungan. Jakarta: Mutiara Sumber Widya.

Bovy, M. B. dan Lawson, F. (1977). Tourism and Recreation Development: A Handbook of Physical Planning. Boston: CBI Publishing Company

Brigham, J.C. (1991). Social Psychology. New York: Harpercollins Publisher.

Daniels, B. C. (1995). Puritans at Play Leisure and Recreation in Colonial New England. New York: St. Martin's Press.

Definisi Kontekstual. (2020). Diakses 15 Februari 2020, dari https://en.wikipedia.org/wiki/Contextual_architecture.

Definisi Lokakarya. (2020). Diakses 20 Juni 2020, dari https://kbbi.web.id/lokakarya

Definisi Pengelolaan Sampah. (2020). Diakses 20 Juni 2020, dari https://id.wikipedia.org/wiki/Pengelolaan_sampah

Definisi Recreation. (2020). Diakses 15 Februari 2020, dari https://en.wikipedia.org/wiki/Recreation

Definisi Rekreasi. (2020). Diakses 15 Februari 2020, dari https://id.wikipedia.org/wiki/Rekreasi

Definisi Sanggar. (2020). Diakses tanggal 20 Juni 2020, dari https://id.wikipedia.org/wiki/Sanggar

Definisi Sanggar. (2020). Diakses 20 Juni 2020, dari https://kbbi.web.id/sanggar

Definisi Third Place. (2020). Diakses 15 Februari 2020, dari https://en.wikipedia.org/wiki/Third_place

Heimstra, N.W. dan McFarling L.H. (1978). Enviromental Psychology 2nd Edition. California : Brooks / Cole Publishing Company.

Holahan, C. J. (1982). Environmental Psychology. New York: Random House.

Jormakka, K. (2008). Basics Design Methods. Berlin: Birkhauser Verlag AG.

Kodoatie, R. J. (2003). Manajemen dan Rekayasa Infrastruktur. Yogyakarta: $\quad$ Pustaka Pelajar.

Oldenburg, R. (1989). The Great Good Place. US: Da Capo Press.

Panduan Komplit Benda yang Bisa Didaur Ulang. Diakses 20 Juni 2020, dari https://waste4change.com/w4c-recyclables/2/

Pengertian Dari Unsur - Unsur Pembentuk Kota. Diakses 20 Juni 2020, dari https://scribd.com/document/339972170/Pengertian-Dari-Unsur 
Penjelasan Konsep Hijau 3R. Diakses 20 Juni 2020, dari https://waste4change.com/waste4change-supports-3r-reduce-reuse-recycle-greenconcept/2/

Sujarto, D. (1995). Perencanaan Kota Baru. Bandung: Penerbit ITB. 